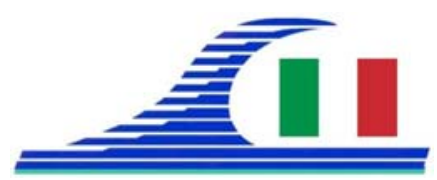

Conférence Méditerranéenne Côtière et Maritime EDITION 3, FERRARA, ITALIA (2015)

Coastal and Maritime Mediterranean Conference

Disponible en ligne - http://www.paralia.fr - Available online

\title{
Sediment delivery at sea by the Magra River, Northern Italy
}

\section{Sergio CAPPUCCI ${ }^{1}$, Iolanda LISI ${ }^{2}$, Paolo CIAVOLA ${ }^{3}$, Lorenzo ROSSI $^{2}$}

1.ENEA, Via Anguillarese, 301, 3 - 00123 Roma, Italy. sergio.cappucci@enea.it

2. ISPRA, Via Vitaliano Brancati, 00144 Roma, Italy.

iolanda.lisi@isprambiente.it and lorenzo.rossi@isprambiente.it

3. University of Ferrara, Department of Physics and Earth Sciences, Via Saragat 1, 44100 Ferrara, Italy.

cvp@unife.it

\begin{abstract}
:
The present paper describes the geological, geomorphological and hydrological characteristics of the catchment area of the Magra River, providing an estimate of the bed load sediment deliver through two methodological approaches: the first one is based on the results of field measurements conducted between 1999 and 2000 by the local authorities of Massa Carrara; the second one is based on the application of available empirical formulations. The range of the obtained results is between $35 \times 10^{3}$ and $68.5 \times 10^{3} \mathrm{~m}^{3} / \mathrm{y}$ which are comparable to previous investigation of WL DELFT HYDRAULICS (2006) and CAVAZZA (1977) and are higher compare to estimation derived from field measurements carried out at the Calamazza section in the upper part of the basin.
\end{abstract}

Keywords: Bed load transport, Sediment delivery, ICZM, Natural capital.

\section{Introduction}

The estimate of sediment delivery from rivers is a critical issue for the economic development of the Apuan-Versilia coast, which is subject to intense erosion processes (CIPRIANI et al., 2001; PRANZINI, 2004), strongly influenced by anthropogenic impacts (AMINTI et al., 2002; CAPPUCCI et al., 2011). The analysis of the evolutionary trend of the coastal system requires investigating sedimentary processes at the scale of the Physiographic Unit (WL DELFT HYDRAULICS, 2006) and Catchment area (RINALDI \& SURIAN, 2005), including reservoirs (ONORI et al., 2006; PIEGAY \& RINALDI, 2006).

The sediment delivery of the Magra River was previously investigated by:

1) CAVAZZA (1977), which estimated the value between $72 \times 10^{3} \mathrm{~m}^{3} / \mathrm{y}$ and $338 \times 10^{3}$ $\mathrm{m}^{3} / \mathrm{y}$.

2) The River Basin Authority (2005), which had monitored the values at the mouth as a result of a flood event of November of 1999, calculating the volumetric changes occurred at the river bed. 
Côtes méditerranéennes menacées :

Risques et défis dans le contexte du changement climatique

3) The Dutch institute WL DELFT HYDRAULICS (2006) which identified in the River Magra a major source of sediment input calculating that, until 1930s bedload transport was about $70-130 \times 10^{3} \mathrm{~m}^{3} / \mathrm{y}$, and decreased trough time due to intense excavation for the aggregates needed to build the embankments of highways.

\section{Study area}

The Magra River has a length of about $62 \mathrm{~km}$ and flows with an average slope of $2 \%$ into the Tyrrhenian Sea following a dendritic pattern. During the time interval 19652000, the water level measurements have showed an increase in the average annual water discharge varying from 54.4 to $73.83 \mathrm{~m}^{3} / \mathrm{s}$ (UFFICIO DEL GENIO CIVILE DI MASSA CARRARA, 2000); its catchment area is $\sim 1.720 \mathrm{~km}^{2}$ (Fig. 1) and three artificial barriers (Giaredo, Rocchetta and S. Margherita di Vara) entrapped 5,5 million $\mathrm{m}^{3}$ of sediment. Limestone, sandstone and limited outcrops of massive rocks, where erosion is active, characterise the river valley and the morphological changes of the riverbed are related to variations in water discharge (RINALDI \& SIMONCINI, 2006).

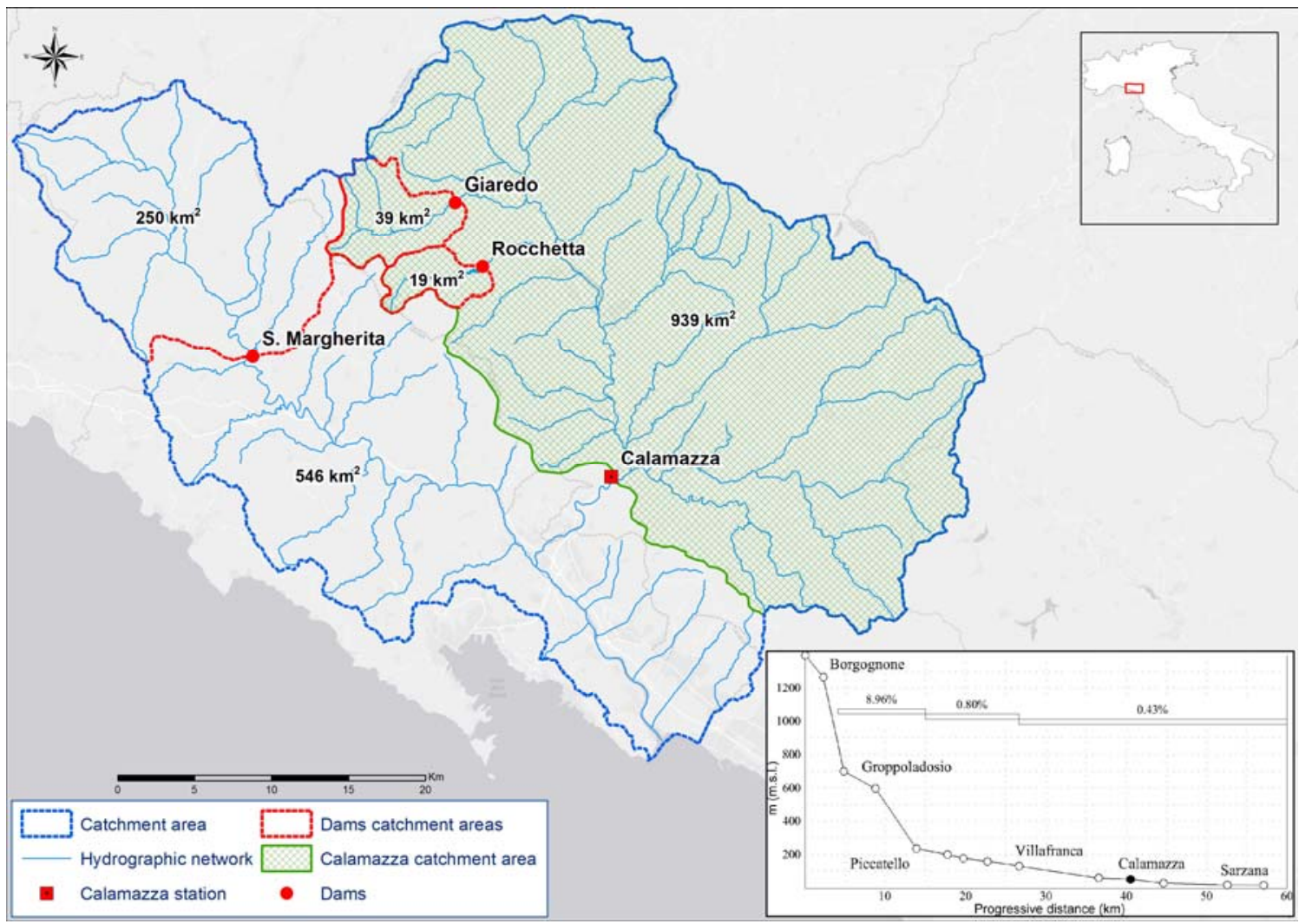

Figure 1. Magra River catchment area at Calamazza station $\left(939 \mathrm{~km}^{2}\right)$ and location of rainfall and hydrometric stations along the river cross-section.

Thirty rainfall stations, which have been operative since 1925, measured an average precipitation rate of about $1700 \mathrm{~mm} / \mathrm{y}$ and an annual runoff coefficient of 0.75 
(D'AQUINO, 1989). Based on the lithological and hydrological characteristics of the river it can be assumed that sediment transport is relevant, especially for larger size fractions, occurring mostly only during major hydrometric events (BASIN AUTHORITY, 2000; 2005).

\section{Materials and methods}

The bed-load sediment transport of the Magra River was estimated, based on field measurements and the application of available empirical formulations.

In situ measures collected from March 1999 to October 2000 at Calamazza station, located $22 \mathrm{~km}$ far from the River mount (Figure 1), were used (Ufficio del Genio Civile di Massa Carrara, 2000). In particular, water level and water discharge time-series as well as sampling of bottom sediments (six samples collected during each field campaign by deploying an Halley Smith-trap), were preliminary analyzed. The most significant information obtained by this dataset are reported in Table 1.

Given the hourly time series of water level Y (m) and an average width of river section of $50 \mathrm{~m}$, the following linear relationship between the water discharge ( $\mathrm{Q}$ in $\mathrm{m}^{3} / \mathrm{s}$ ) and the associated bed-load transport ( $\mathrm{P}$ in $\mathrm{kg}$ ) per unit width across the river section was found:

$\mathrm{P}=0.0004 * \mathrm{Q} \quad\left(\mathrm{r}^{2}=0.99\right)$

Thus, given the rating curve $\mathrm{Y}=0.3445^{*} \mathrm{Q}^{0.3386}$, an estimation of the average annual bedload is obtained by hourly time-series of the water discharge and the related measured of bedload transport.

In addition, to better estimate the solid volumetric flow rate per unit width across the river section $\left(\mathrm{m}^{3} / \mathrm{s} / \mathrm{m}\right)$, three empirical formulations were applied: (1) MEYER-PETER \& MULLER-MPM (1948); (2) SCHOKLITSCH (1962); (3) SMART \& JAEGGI (1983). These formulations allow estimating the bed-load sediment transport (expressed in $\mathrm{m}^{3} / \mathrm{y}$ ) as a function of the sediment proprieties of the river bed and of hydrological and morphological parameters derived by field data.

In this case, the rating curve was discretized in a daily time-series and related daily flow-rate values were obtained. Then, daily bed-load sediment transport values were estimated by the application of selected empirical formulations. The mean bedload annual value of was finally calculated as the amount of all daily estimated contributions. In particular, in order to estimate the bed-load transport at the Calamazza station, the sediment grain size $\left(D_{50}\right)$, based on grain size analysis, was imposed equal to $1 \mathrm{~cm}$, the weight of the unit volume $(\gamma \mathrm{s})$ equal to $2.7 \mathrm{t} / \mathrm{m}^{3}$ and the slope of the river bed equal to $0.4 \%$. While, sensivity analysis were performed to define the most appropriate values of the dimensional and adimensional coefficients in the formulations, based on ranges resulting from a specific literature review.

The bed-load sediment at the mouth of the Magra River was then calculated by relating the whole catchment area of the Magra River $\left(1720 \mathrm{~km}^{2}\right)$ with the catchment area at the 
Côtes méditerranéennes menacées :

Risques et défis dans le contexte du changement climatique

Calamazza station (939 $\mathrm{km}^{2}$ ), both considering and not the contribution of the catchment areas of the S.M. Vara's dam.

Table 1. Field campaigns, average value of water discharge, derived from water level, and weight of samples (UFFICIO DEL GENIO CIVILE DI MASSA CARRARA, 2000).

\begin{tabular}{lll|lll}
\hline $\begin{array}{l}\text { Field } \\
\text { campain }\end{array}$ & $\begin{array}{l}\text { Discharge } \\
\left(\mathbf{m}^{3} / \mathbf{s}\right)\end{array}$ & $\begin{array}{l}\text { Weight } \\
(\boldsymbol{g})\end{array}$ & $\begin{array}{l}\text { Field } \\
\text { campain }\end{array}$ & $\begin{array}{l}\text { Discharge } \\
\left(\mathbf{m}^{3} / \mathbf{s}\right)\end{array}$ & $\begin{array}{l}\text { Weight } \\
(\boldsymbol{g})\end{array}$ \\
\hline $08 / 05 / 1999$ & 28 & 29.05 & $28 / 10 / 1999$ & 42 & 79.05 \\
\hline $11 / 06 / 1999$ & 8 & 19.08 & $12 / 01 / 2000$ & 25 & 26.03 \\
\hline $10 / 08 / 1999$ & 3 & 14.02 & $29 / 03 / 2000$ & 415 & 836.08 \\
\hline
\end{tabular}

\section{Results}

Results of bed-load sediment transport obtained at Calamazza station and at the mouth of the Magra River, are reported in Table 2 (from field surveys) and Table 3 (from empirical formulas considering $(*)$ or not $(* *)$ the contribution of the catchment areas of the S.M. Vara's dam.

Table 2. Values of bedload transport estimated at Calamazza from in situ sampling and at the mouth of Magra River.

\begin{tabular}{llll}
\hline Station & Calamazza & \multicolumn{2}{l}{ River mouth } \\
\hline Basin extention $\left(\mathrm{km}^{2}\right)$ & 939 & $1720^{*}$ & $1470 * *$ \\
\hline Bedload transport $\left(\mathrm{m}^{3} / \mathrm{y}\right)$ & $22.6 \cdot 10^{3}$ & $42.4 \cdot 10^{3}$ & $34.9 \cdot 10^{3}$ \\
\hline
\end{tabular}

Table 3. Values of bedload transport estimated through empirical equations.

\begin{tabular}{llll}
\hline Station & Calamazza & River mouth & \\
\hline Basin $\left(\mathrm{km}^{2}\right)$ & 939 & $1720 *$ & $1470 * *$ \\
\hline Used equation & Bedload Transport $\left(\mathbf{m}^{3} / \mathrm{y}\right)$ & \\
\hline Schoklitsch $(\mathrm{K}=5000)$ & $43.8 \cdot 10^{3}$ & $80.2 \cdot 10^{3}$ & $68.5 \cdot 10^{3}$ \\
\hline Meyer-Peter and Muller-MPM & $40.9 \cdot 10^{3}$ & $76.6 \cdot 10^{3}$ & $63.1 \cdot 10^{3}$ \\
\hline Smart and Jaeggi & $43.5 \cdot 10^{3}$ & $81.4 \cdot 10^{3}$ & $67.0 \cdot 10^{3}$ \\
\hline Average values & $42.7 \cdot 10^{3}$ & $79.4 \cdot 10^{3}$ & $66.2 \cdot 10^{3}$ \\
\hline
\end{tabular}

\section{Conclusion}

The application of empirical formulas for estimating the river sediment transport requires the use of parameters that, due to various limitations, can provide results that differ from the real sediment delivery. However, in the present paper, by virtue of particular lithological and hydrological behaviour of Magra River, the results obtained by the application of empirical formulations $\left(63.1^{* *}-80.2^{*} \times 10^{3} \mathrm{~m}^{3} / \mathrm{y}\right)$ are comparable to previous investigation of WL DELFT HYDRAULICS (2006; 70-130 $\times 10^{3} \mathrm{~m}^{3} / \mathrm{y}$ ) and 
CAVAZZA (1977) and are $150 \%$ higher compare to estimation derived from field measurements carried out during water discharge (34.9-42.4 $\left.\times 10^{3} \mathrm{~m}^{3} / \mathrm{y}\right)$.

It is observed that the lower values of bedload sediment transport, estimated by relating the water discharge time-series with field measurements of bottom sediments, can be due to: (a) the reduced river flow rate (varying from $3 \mathrm{~m}^{3} / \mathrm{s}$ to $415 \mathrm{~m}^{3} / \mathrm{s}$ ) occurred during the short time interval (03/1999-4/2000) of measurements; (b) to the absence of sediment samples in the central part of river cross-section at Calamazza station and (c) the real transport capacity of the river sand in the section between Calamazza and Magra River mouth, where processes of deposition are known and under investigation To notice that out of the three formulas tested, only the MPM is strictly speaking applicable to the geomorphological context of the Magra in the lower course. Although the other two formulas were tested, they are more appropriate for rivers with steep beds and narrow alluvial plains.

\section{Acknowledgements}

The present work was developed in the framework of the Marina di Carrara technical committee, established by the Italian Ministry of Environment. Thanks also to Prof. Andrea Rinaldo, Paolo Billi, Pietro Colonna, Stefano Corsini for suggestions.

\section{References}

AMINTI P., CAMMELLI C., PELLICCIA F., PRANZINI E. (2002). Beach Response to a Submerged Groin Field (Marina dei Ronchi, Italy). Proceedings Intern. MedCoast workshop on beaches of the Mediterranean and the Black Sea, Kusadasy, Turchia. Erdal Ozhan Ed., pp 71-82.

BASIN AUTHORITY -Autorita di Bacino del Fiume Magra- (2000). Studio per il Piano Stralcio di Bacino del Fiume Magra: Elaborazione statistica dei dati di portata finalizzata alla valutazione della portata idrica. Rapporto Tecnico, 68 p.

BASIN AUTHORITY -Autorita di Bacino Interregionale del Magra- (2005). Messa in sicurezza idraulica delle aree prospicienti il tratto focivo del fiume Magra. Rapporto Tecnico, $51 \mathrm{p}$.

CAPPUCCI S., SCARCELLA D., ROSSI L., TARAMELLI A. (2011). Integrated coastal zone management at Marina di Carrara Harbor: sediment management and policy making. Ocean \& Coastal Management, Vol. 54(4), pp. 277-289. http://dx.doi.org/10.1016/j.ocecoaman.2010.12.006

CAVAZZA S. (1977). I criteri di stima dell'apporto terrigeno alla foce dei corsi d'acqua e il caso del fiume Magra. Atti del Convegno di Studi per il Riequilibrio della Costa fra il Fiume Magra e Marina di Massa. 
Côtes méditerranéennes menacées :

Risques et défis dans le contexte du changement climatique

CIPRIANI L.E., FERRI S., IANNOTTA P., PAOLIERI F., PRANZINI E. (2001). Morfologia e dinamica dei sedimenti del litorale della Toscana settentrionale. Studi costieri, Vol. 4, pp 119- 156.

D’AQUINO D. (1989). Idrogeologia della bassa Val di Magra e considerazioni ideologiche sul tratto terminale del Fiume Magra. Università degli Studi di Pisa. Tesi di laurea, $170 \mathrm{p}$.

MEYER-PETER E., MÜLLER R. (1948). Formulas for bed-load transport. In: Proceedings of the 2nd Meeting of the International Association for Hydraulic Structures Research, Delft, Netherlands, pp 39-64.

ONORI F, GRAUSO, S., REGINA P., PASANISI F., TEBANO C., FELICI F., MARCINO M.A. (2006). Erosion and sediment supply capacity in two watersheds of Sicily (Southern Italy): a comparison from reservoir sedimentation data. Geologia Tecnica ed Ambientale, Vol. 3-4/06, pp 47-60.

PIEGAY H., RINALDI M. (2006). Gestione sostenibile dei sedimenti in fiumi ghiaiosi incisi in Francia. Atti Giornate di Studio "Nuovi approcci per la comprensione dei processi fluviali e la gestione dei sedimenti. Applicazioni nel bacino del Magra." Sarzana, Autorità di Bacino del Fiume Magra, pp 59-80.

PRANZINI E. (2004). Caratteristiche Morfologiche e Sedimentologiche di una zona di convergenza del trasporto litoraneo (Versilia, Toscana). Studi costieri, Vol. 8, pp 135149.

RINALDI M., SURIAN N. (2005). Variazioni morfologiche ed instabilità di alvei fluviali: metodi ed attuali conoscenze sui fiumi italiani. In: M.Brunelli and P. Farabollini (Eds), Dinamica Fluviale, Atti Giornate di Studio sulla Dinamica Fluviale, Grottammare, Giugno 2002, Ordine dei Geologi Marche, pp 203-238.

RINALDI M., SIMONCINI C. (2006). Studio geomorfologico del Fiume Magra e del Fiume Vara finalizzato alla gestione dei sedimenti e della fascia di mobilità. Atti Giornate di Studio "Nuovi approcci per la comprensione dei processi fluviali e la gestione dei sedimenti. Applicazioni nel bacino del Magra." Sarzana, Ottobre 2006, Autorità di Bacino del Fiume Magra, pp 93-109.

SCHOKLITSCH A. (1962). Handbuch des Wasserbaues. 3rd edn. Springer, Vienna, $475 \mathrm{p}$.

SMART G.M., JAEGGI M., (1983). Sediment transport in steiler Gerimmen. Sediment transport on steep slopes. Mitterilug der Versuchsanstelt für Wasserban, Hydrologie und Glaziologie der ETH Zürich, 64 p.

UFFICIO DEL GENIO CIVILE DI MASSA CARRARA (2000). Determinazione $e$ stima del trasporto solido di fondo nelle tre stazioni di Calmazza (Comune di Aulla) Santa Giustina e Piccatelo (Comune di Pontremoli) sul fiume Magra in Provincia di Massa Carrara, 118 p.

WL DELFT HYDRAULICS (2006). Carrara Coastal Study Volume 3: Coastline Evolution Study. Draft Report, 211 p. 